\title{
嗅覚障害症例における嗅覚検査と予後
}

\author{
上原健・金澤 丈治・長谷川昌宏 \\ 宇良 政治・野田＼cjkstart寛・東野 哲也
}

\section{A Clinical Study of Olfactory Disturbance}

\author{
Ken Uehara, Takeharu Kanazawa, Masahiro Hasegawa, \\ Masaharu Ura, Yutaka Noda and Tetsuya Tono \\ (University of the Ryukyus)
}

\begin{abstract}
Recently, olfactory disturbance caused by various diseases has been an important symptom. In this study, 76 patients with olfactory disturbance seen at University of the Ryukyus Hospital between 1997 and 2001 were analyzed. Distribution of the disease caused by olfactory disturbance was as follows: 26 cases of rhinosinusitis, 47 of viral infection and 3 of head trauma. Patient characteristics, initial treatment and results of $\mathrm{T} \& \mathrm{~T}$ olfactometry or intravenous olfactometry (Alinamin ${ }^{\circledR}$ test) did not significantly differ between the rhinosinusitis group and the viral infection group. To investigate whether the prognosis could be estimated by $\mathrm{T} \& \mathrm{~T}$ olfactometry and intravenous olfactometry, the initial results of $\mathrm{T} \& \mathrm{~T}$ olfactometry or intravenous olfactometry and improvements after treatment were longitudinally compared in the rhinosinusitis group and in the viral infection group. As a result, improvements in the disturbance were significantly correlated with $\mathrm{T} \& \mathrm{~T}$ olfactometric findings in both groups. Similarly, improvements were significantly correlated to findings on olfactometry. These results suggested that initial examination for olfactory disturbance should be able to estimate the prognosis of the disturbance caused by various diseases.
\end{abstract}

Key words : olfactory disturbance, $\mathrm{T} \& \mathrm{~T}$ olfactometry, Alinamin ${ }^{\circledR}$ test, prognosis

\section{はじめに}

近年，嗅覚障害は一般の関心も高まり，これに伴って 嗅覚障害を主訴に外来を受診する例も増加している．嗅 覚障害患者の治療にあたって，その予後を推定すること は治療方針の決定，患者への説明のために必要と考えら れる. 今回, われわれは嗅覚障害を主訴に受診した症例 を原因疾患別に分類し初診時の嗅覚検查と予後との関係 につき検討したので若干の文献的考察を加え報告する.

\section{対象と方法}

対象は 1997 年 1 月から 2001 年 12 月までの 5 年間に嗅 覚障害を主訴に琉球大学医学部付属病院耳鼻咽喉科を受 診した症例のうち原因疾患が特定でき, 3 カ月以上経過観
察できた症例 76 例である.

原因疾患は病歴, 前鼻鏡所見, 鼻副鼻腔ファイバース コープ，針状硬性鏡，CT を含む画像診断の結果により 分類した。

検討した事項は患者背景, 原因疾患, 発症から受診ま での病悩期間および病悩期間と予後との関係, 初診時の 基準嗅力検査（T＆ T オルファクトメトリー）の結果, 静脈性嗅覚検査（アリナミン®テスト）の結果, さらに は，これらの検查結果と予後との関係である。嗅覚検査 と予後との関係を明らかにするために嗅覚の程度を $\mathrm{T} \&$ T オルファクトメトリーの認知閾値の平均値から軽度・ 中等度障害群 (4.0 以下), 高度障害群 $(4.1 \sim 5.5)$, 脱 失群（5.6 以上）に分類した. また，アリナミン ${ }^{\circledR}$ テス 
トの潜時を $1 \sim 30$ 秒， $31 \sim 60$ 秒， 61 秒以上に分類し， 持続時間は 0 秒 (無反応), $1 \sim 30$ 秒， $31 \sim 80$ 秒， 81 秒以上に分類した. 予後の判定は, 主に自覚的改善度で 行い，森 ${ }^{1)}$ の評価による治癒例および改善例を改善例と し，治療後に T \& T オルファクトメトリーを施行できた 例に関しては認知間值の平均が 2 段階以上の改善がみら れたものを改善例とした。

嗅覚検查と予後との関係は, それぞれの障害の程度ご との改善率の変化をマン・ホイットニーの U 検定を用い て検定した.

\section{結 果}

患者背景：対象症例の性別は，男性 29 例，女性 47 例 と女性に多く, 年齢は 9 〜 82 歳で平均年齢は 51.7 歳で あった。年代別では 60 歳代が最多であった。

原因疾患: 原因疾患は, 鼻汁過多, 鼻茸, 鼻中隔弯曲, 下鼻甲介の腫脹などの鼻腔内形態異常を伴うもの（鼻副 鼻腔炎群） 26 例，先行する感冒症状を認め，鼻腔内形態 異常を伴わないもの（感冒群）47 例，明らかな頭部外傷 を伴うもの（外傷群） 3 例の 3 群に分類できた。これら のうち症例数が比較的多く，検討が可能と思われた鼻副 鼻腔炎群 26 例, 感冒群 47 例につき以下の検討を行った. 治療法: 鼻副鼻腔炎群と感冒群の治療法を図 1 に示す。 鼻副鼻腔炎群では, 手術が 11 例施行されていたが, 保存
的治療では両群ともステロイドの局所投与が最も多く, その他，抗アレルギー剤の投与やビタミン B12 製剤の投 与が行われていた。 また, 重症例の一部では, ステロイ ドの全身投与も行われていた.

病悩期間（図 2)：症状出現から受診までの期間は感冒 群では最短の症例が症状出現後 3 日で受診し, 病悩期間 が 6 カ月以下の症例が 28 例 (59.6\%) と半数以上であり, 鼻副鼻腔炎群は最短の症例が1カ月で 6 力月以内に受診し た症例が 7 例 (26.9\%) と全体に感冒群の方が症状出現 後早期に受診する傾向にあった。

病悩期間を 6 力月以内と 7 月以上の 2 つに分類し，マ ン・ホイットニーの U 検定を用いて検定すると，鼻副鼻 腔炎群では有意差を認めなかったものの, 感冒群では6カ 月以内の症例は有意に改善率が高かった $(P<0.01)$.

$\mathrm{T} \& \mathrm{~T}$ オルファクトメトリー: 両群の $\mathrm{T} \& \mathrm{~T}$ オルファク トメトリーでの認知嗅力損失の結果を図 3 亿示す．認知 嗅力損失は両群とも嗅覚障害の程度が高いほど症例数が 増加する傾向にあり，全体として両群間で同様な傾向を 示した。

アリナミン ${ }^{\circledR}$ テスト : アリナミン ${ }^{\circledR}$ テストの潜伏時間 を 10 秒以下, $11 \sim 30$ 秒， $31 \sim 60$ 秒， 61 秒以上に分類 すると両群の症例数はほぼ同様な傾向を示し(図 $4 \mathrm{a}$ ), 持 続時間を 0 秒 (無反応)，1〜30 秒， $31 \sim 80$ 秒, 81 秒 以上に分類した場合も両群ともほぼ同様な傾向を示した

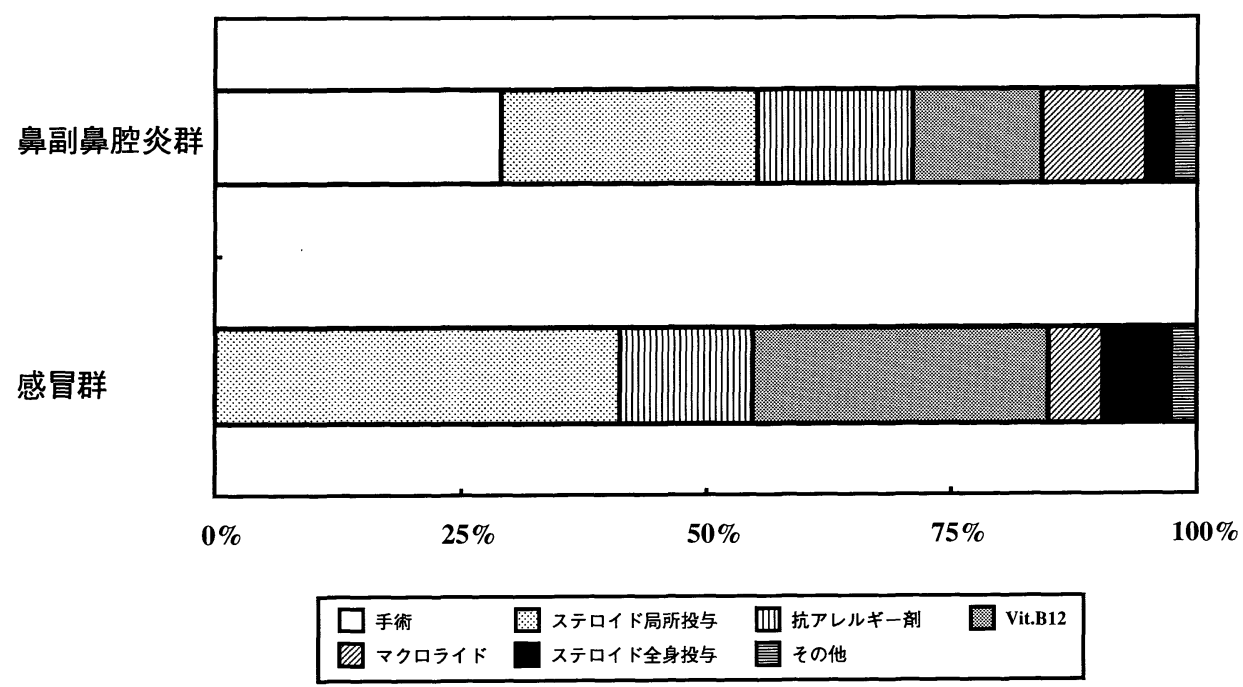

図 1 治療法

鼻副鼻腔炎群では，11 例で手術が施行されていたが，保存的治療は両群ともステロイドの 局所投与が最も多かった。（重複例あり） 


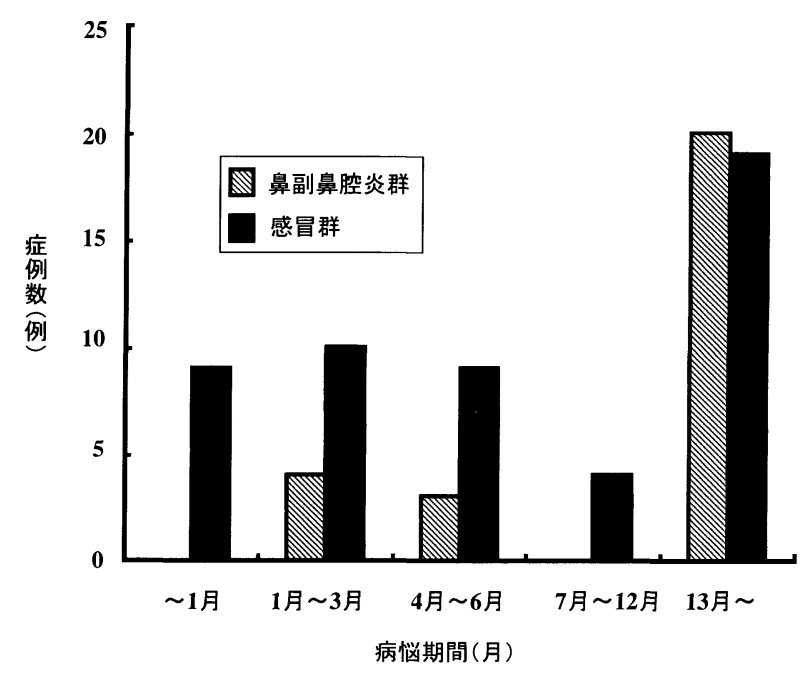

図 2 病悩期間

鼻副鼻腔炎群・感冒群の両群を比較すると感冒群が早期 に受診する傾向にあった。

(図 $4 \mathrm{~b}$ ).

$\mathrm{T} \& \mathrm{~T}$ オルファクトメトリーと予後: 鼻副鼻腔炎群, 感 冒群ごとに認知嗅力損失が軽度 ・ 中等度障害群 (4.0 以 下), 高度障害群 $(4.1 \sim 5.5)$, 脱失群（5.6 以上）に分 類し，予後との関係を検討した (図 5). 鼻副鼻腔炎群の 軽度・中等度障害群での改善率が 7 例中 7 例 (100\%), 高度障害群が 6 例中 4 例 $(66.7 \%)$, 脱失群が 11 例中 4 例 $(36.4 \%)$ であり（図 $5 \mathrm{a}$ ), 感冒群はそれぞれ 19 例中 13 例 $(68.4 \%), 12$ 例中 7 例 $(58.3 \%), 15$ 例中 1 例 $(6.7$

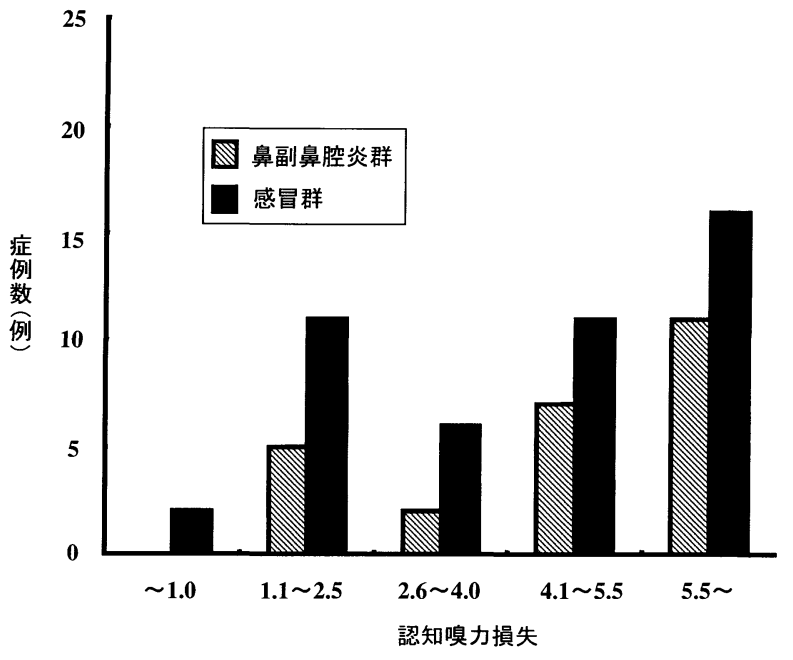

図 3 T \& T オルファクトメトリー 鼻副鼻腔炎群・感冒群の両群とも同様の傾向を示した。

\%) であった（図 $5 \mathrm{~b}$ )。このように両群ともに認知嗅力 損失の值が上昇するに従って，改善率は有意に低下した $(P<0.01) . こ の こ と は$ 鼻副鼻腔炎群・感冒群の両群で 治療前の認知嗅力損失の值はその予後を反映することが 示された.

アリナミン ${ }^{\circledR}$ テストと予後 : 鼻副鼻腔炎群, 感冒群ご とに治療開始前のアリナミン ${ }^{\circledR}$ テスト潜伏時間の長さを $1 \sim 30$ 秒, $31 \sim 60$ 秒， 61 秒以上に分類し, 改善率を検 討した. 鼻副鼻腔炎群の改善率は $1 \sim 30$ 秒では 12 例中 10 例 $(83.3 \%), 31 \sim 60$ 秒では 2 例中 0 例 $(0 \%), 61$

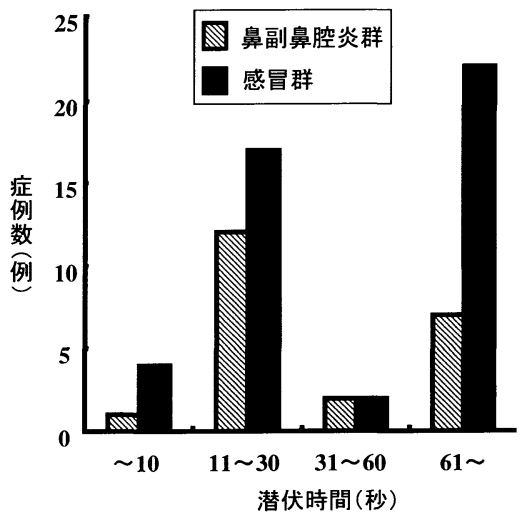

a

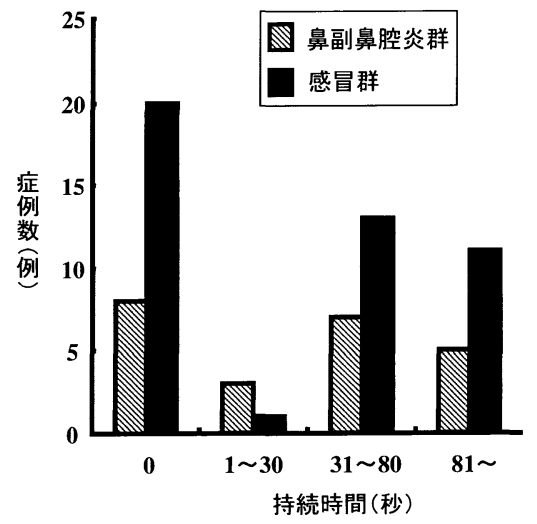

b

図 4 アリナミン ${ }^{\circledR}$ テスト

a）潜伏時間. 潜伏時間は, 鼻副鼻腔炎群・感冒群の両群とも同様の傾向を示した.

b) 持続時間. 持続時間も両群とも同様の傾向を示した. 


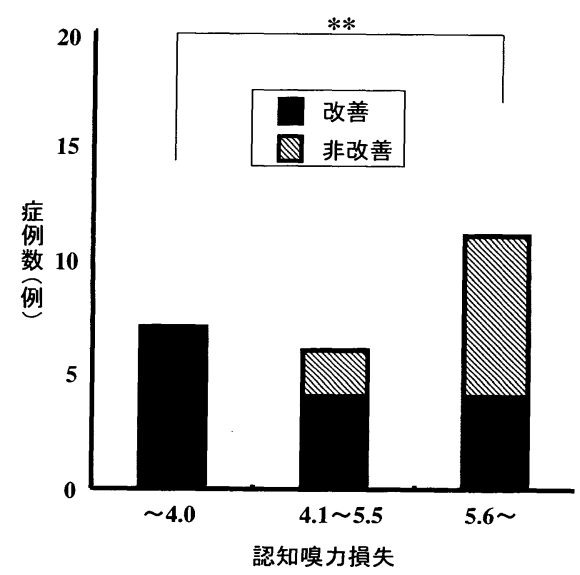

a

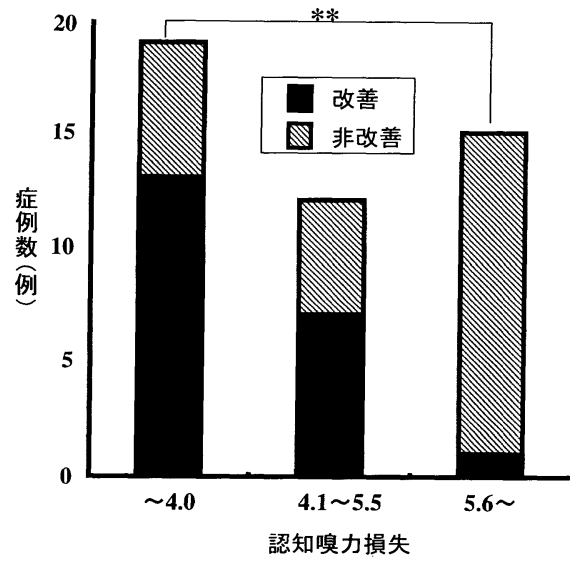

$\mathrm{b}$

図 5 T \& T オルファクトメトリーと予後

a）鼻副鼻腔炎群. 鼻副鼻腔炎群で, $\mathrm{T} \& \mathrm{~T}$ オルファクトメトリーの結果は予後を反映した.

b）感冒群. 感冒群でも同樣に T \& T オルファクトメトリーの結果は予後を反映した.

(マン・ホイットニーの U 検定 : ** $P<0.01$ )

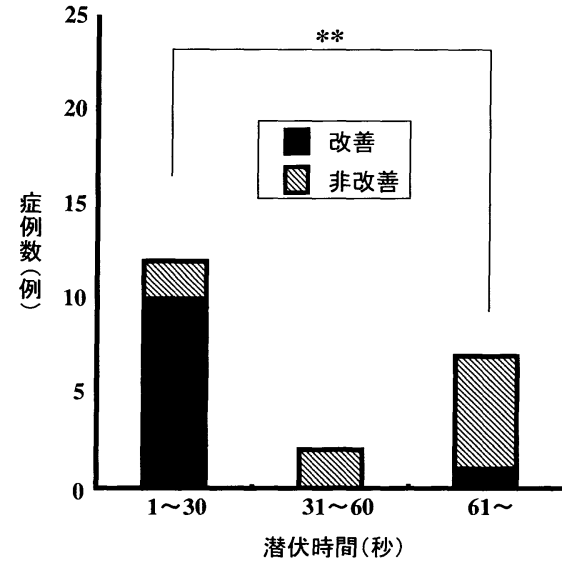

a

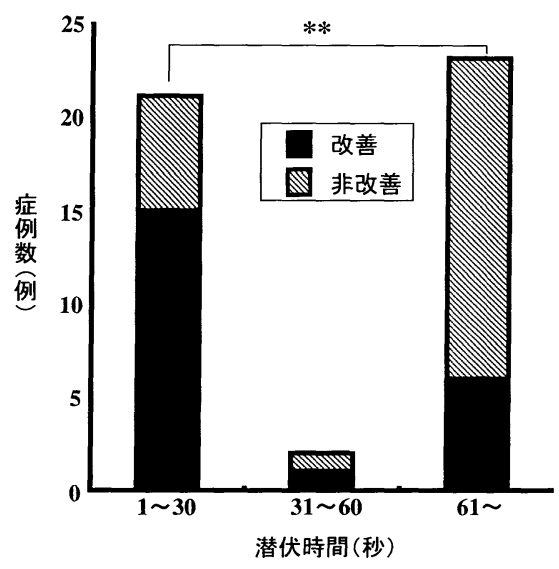

$\mathrm{b}$

図 6 アリナミン® テスト潜伏時間と予後

a）鼻副鼻腔炎群。鼻副鼻腔炎群で，アリナミン®テストの潜伏時間はその予後を反映した.

b）感冒群. 感冒群でも同様に潜伏時間はその予後を反映した.

(マン・ホイットニーの U 検定 : ** $P<0.01$ )

秒以上では改善率が 7 例中 1 例（14.2\%）（図6a）であ り，感冒群はそれぞれ 21 例中 15 例 $(71.4 \%) ， 2$ 例中 1 例 $(50.0 \%) ， 23$ 例中 6 例 $(26.1 \%$ ) であった（図 $6 \mathrm{~b}$ ). このように副鼻腔炎群・感冒群の両群で潜伏時間が 61 秒 以上では 30 秒以下と比較して改善率は有意に減少した $(P<0.01)$. このことは, 鼻副鼻腔炎群・感冒群の両群 で治療前のアリナミン ${ }^{\circledR}$ テストの潜伏時間はその予後を 反映すると考えられた。
次に,アリナミン ${ }^{\circledR}$ テストの持続時間を 0 秒 (無反応), $1 \sim 30$ 秒, $31 \sim 80$ 秒, 81 秒以上に分類すると, 鼻副鼻 腔炎群の改善率は 0 秒で 7 例中 1 例 (14.3\%), $1 \sim 30$ 秒では 3 例中 2 例 $(66.7 \%), 31 \sim 80$ 秒では 7 例中 5 例 $(71.4 \%), 81$ 秒以上では 4 例中 3 例 $(75.0 \%)$ であり (図 $7 \mathrm{a}$ )，持続時間が延長するほど，改善率は有意に上昇 した $(P<0.01)$. 感冒群でもそれぞれ 23 例中 6 例 $(26.1$ $\%), 1$ 例中 1 例 $(100 \%), 11$ 例中 7 例 $(63.6 \%), 11$ 例 


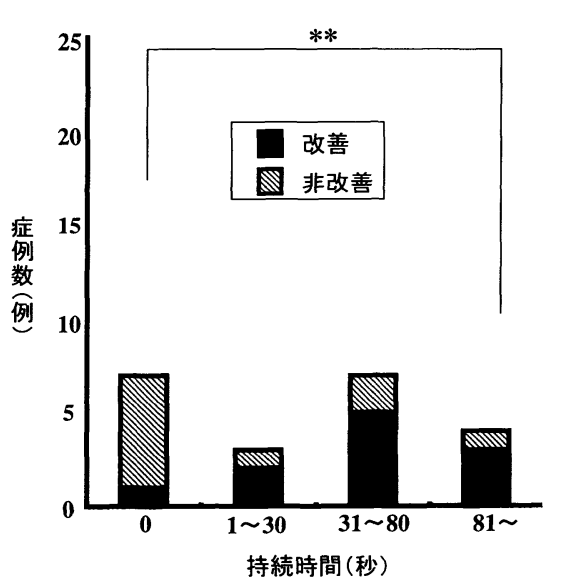

a

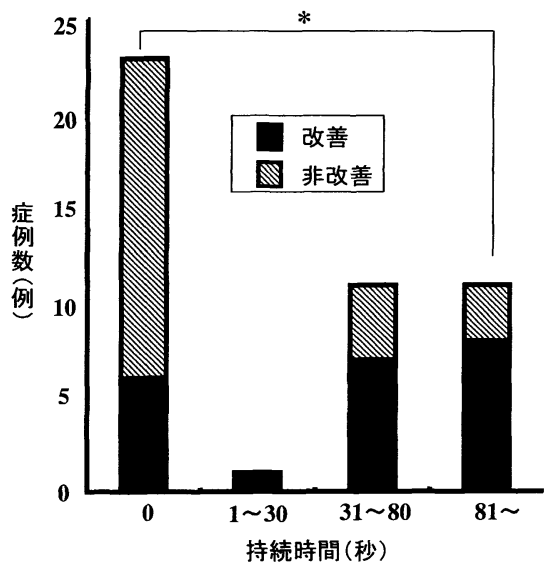

b

図 7 アリナミン ${ }^{\circledR}$ テスト持続時間と予後

a）鼻副鼻腔炎群. 鼻副鼻腔炎群で, アリナミン®テストの持続時間はその予後を反映した.

b）感冒群. 感冒群でも同様に持続時間はその予後を反映した.

（マン・ホイットニーの U 検定 : ** $P<0.01, * P<0.05$ )

中 8 例 $(72.7 \%)$ であり（図 $7 \mathrm{~b})$, 持続時間の延長に従 い, 改善率は有意に上昇した $(P<0.05)$.このようにア リナミン ${ }^{\circledR}$ テストでも潜伏時間, 持続時間ともにその予 後を反映すると考えられた。

\section{考察}

嗅覚障害を訴えて耳鼻咽喉科外来を受診する患者は近 年増加傾向にあるとされている，嗅覚障害患者の治療に あたって, 患者背景を理解しその予後を推定することは 治療方針の決定, 患者への説明のために重要である. 一 般の耳鼻咽喉科外来では嗅覚検査としてはアリナミン ${ }^{\circledR}$ テストや T\& T オルファクトメトリーが頻用されてい る.われわれは, 嗅覚障害患者の診療の実態や嗅覚検査 と予後との関係を知るために今回の検討を行った.

今回検討した症例は, 性別では男性 29 例, 女性 47 例 と女性に多い. 他の報告でも女性に多いという報告はみ られ2) 4), 性ホルモンの影響などが推測されている が5), 一方で有意差を認めないという報告も多い677). 今 回の検討では, 性周期との関連についての検討は行って おらず，詳細は不明である．また，受診時の年齢分布で は平均 51.7 歳で 60 歳代が最多であり, 中高年者に多い という点で他の報告と同様であった ${ }^{27)}$. 原因疾患は鼻腔 内形態異常を認める鼻副鼻腔炎群と先行する感冒症状を 認め鼻腔内形態異常を伴わない感冒群, さらには, 明ら かな頭部外傷を認めた外傷群に分類できたが, 鼻副鼻腔
群が26例と感冒群に比較して少ないのは副鼻腔炎やアレ ルギー性鼻炎, 鼻中隔弯曲症の場合は鼻閉や鼻汁過多な どの他の鼻症状を訴えて受診することが多く嗅覚障害を 主訴とすることが少ないためと思われた。

治療法では，保存的治療としてステロイドの局所投与 の有用性が以前より報告されている ${ }^{8)}$. 今回，個々の治 療法と予後との関係を検討することは治療法が重複して いる症例が多く困難であったが, 鼻副鼻腔炎群, 感冒群 の両群とも局所ステロイド投与が多かった. 一方, 手術 は鼻副鼻腔炎群の 11 例で行われたのみである.この手術 例が比較的少ない理由も鼻副鼻腔炎群では他の鼻症状が 前面に出てしまい, 嗅覚障害の訴えが軽視されやすいた めと考えられる。次に, 病悩期間は鼻副鼻腔炎群よりも 感冒群の方が短い傾向にあるが，これは感冒後の嗅覚障 害は発症が急激で自覚しやすいためであると考えられ $た^{3)}$. さらに, 感冒群では, 病悩期間が 6 力月以内の症例 はそれ以上の症例と比較して有意に改善率が高く, 早期 治療の重要性が示唆された.

このように鼻副鼻腔炎群と感冒群を比較すると病悩期 間は感冒群の方が短い傾向にあったが, 治療前の嗅覚検 査でみると T \& T オルファクトメトリー，アリナミン ${ }^{\circledR}$ テストともに分布に大きな隔たりはなかった.

さらに, 今回は鼻副鼻腔炎群, 感冒群について T \& T

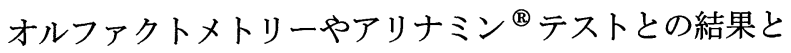
予後との間に関連があるかを検討した．私どもの検討で 
は, 鼻副鼻腔炎群と感冒群の両群で $\mathrm{T} \& \mathrm{~T}$ オルファクト メトリーの結果が重症化するにつれ有意に改善率が低下 し，アリナミン ${ }^{\circledR}$ テストの結果も両群で潜伏時間・持続 時間ともに嗅覚障害の予後を反映した。

このような, 嗅覚検査とその予後に関する検討は現在 までに，いくつか報告されている22319910)。青木ら9) はア リナミン ${ }^{\circledR}$ テストの持続時間と予後は相関すると述べて おり, 江川 10) も慢性副鼻腔炎に伴う嗅覚障害での静脈性 嗅覚検査の重要性を述べている．また白倉ら ${ }^{2)}$ は，T＆ T オルファクトメトリーの嗅覚障害の予後を推定する上 での重要性を述べている，さらに森1) は，嗅覚検查と予 後との関係につき原因疾患別に詳細な検討を行い，鼻副 鼻腔炎群と頭部外傷群では T \& T オルファクトメトリー が予後を推定する因子として重要であり，アリナミン ${ }^{\circledR}$ テストは感冒群においてその予後の推定に重要であると 述べている. しかしながら，これらの報告でも必ずしも すべての嗅覚検查の結果と予後との間に有意差を認めて いるわけではない，今回の検討でも， $\mathrm{T} \& \mathrm{~T}$ オルファク トメトリー，アリナミン ${ }^{\circledR}$ テストともに予後を有意に反 映したものの, 今回の検討がレトロスペクティブな検討 であること, 改善率の評価が主に自覚的改善度に従って いることなどを考慮し，嗅覚障害の診断には他の諸検査 を含む総合的な判断が必要と思われる.

嗅覚障害の評価は，最近になり画像診断を含む新たな 方法11) 13) がいくつか試みられており，さらなる予後の 推測が進んでいる。 しかしながら, 今回検討した T \& T オルファクトメトリーやアリナミン ${ }^{\circledR}$ テストは日常臨床 で頻用される比較的簡便な検查であり，今回の検討から 予後の推定に重要な検查であると考えられる．また，今 回は，嗅覚障害を主訴に受診した症例のみを対象に検討 したが，嗅覚障害を持ちながら鼻閉や鼻汁などの他の症 状を主訴に受診する症例む多いと考えられる。このため 嗅覚障害の治療には，他の鼻症状を主訴に受診した症例 にも嗅覚検查が必要であると思われた.

\section{まとめ}

1. 嗅覚障害を主訴に当科を受診した 76 症例を検討し た.

2. 原因疾患は, 鼻副鼻腔炎群 26 例, 感冒群 47 例, 頭 部外傷群 3 例の 3 群に分類できた.
3. 治療は, 鼻副鼻腔炎群の 11 例で手術が行われたが, ほかは保存的治療が行われステロイドの局所投与が最多 であった。

4. 鼻副鼻腔炎・感冒群の両群で自覚的改善度と $\mathrm{T} \& \mathrm{~T}$ オルファクトメトリーやアリナミン®テストとの間に相 関が認められ，これらの検査は予後の推定に重要と考え られた。

\section{参考文献}

1）森 淳子：嗅覚障害の予後に関する臨床的研究. 耳鼻臨床 $91: 963 \sim 970,1998$

2) 白倉真人, 上條 篤, 中澤真理, 他: 当科における嗅覚障 害患者 102 例に関する統計的観察. 耳鼻臨床 補 $79: 92$ 97, 1995.

3）木村恭之, 作本 真, 山本 環, 他: 感冒罹患後嗅覚障害 の臨床検討. 耳展 $34: 647 \sim 652,1991$.

4) 山際幹和, 三吉康郎, 坂倉康夫, 他 : 当科嗅覚外来の現状 について. 耳鼻臨床 $74: 938 \sim 947,1981$.

5）愛場康雅, 杉本 緑, 森 淳子, 他 : 嗅覚障害の性差に関 する臨床的検討. 日鼻誌 $31: 243 ， 1992$.

6）小宅大輔, 堤康一郎, 肥塚 泉, 他：慢性副鼻腔炎による 嗅覚障害. 聖、医誌 $26: 661 \sim 666,1998$.

7）鳥原康治，永井知幸，狩野季代，他：嗅覚障害症例の検討。 耳鼻 $38 ： 757 \sim 761 ， 1992$.

8) Zusho $\mathrm{H}$, Asaka $\mathrm{H}$ and Okamoto $\mathrm{M}$ : Diagnosis of olfactory disturbance. Auris Nasus Larynx $8: 19 \sim 26,1981$.

9）青木彰彦, 洲崎春海, 周 明人, 他 : 嗅覚障害の臨床的研 究. 耳鼻臨床 $82: 229 \sim 236,1989$.

10）江川雅彦：慢性副鼻腔炎における嗅覚障害. 日耳鼻 $98: 834$ $\sim 854,1995$.

11）中澤真理，今村まゆみ，上條 篤，他：嗅覚障害患者にお けるMRI の有用性について. 耳鼻臨床 補 79:87 91, 1995.

12) Ishimaru $T$, Shimada $T$, Miwa $T$, et al. : Electrically stimulated olfactory evoked potential in olfactory disturbance. Ann Otol Rhinol Laryngol $111: 518 \sim 522,2002$.

13) Ikeda $K$, Tabata $K$, Oshima $T$, et al. : Unilateral examination of olfactory threshold using the Jet Stream Olfactometer. Auris Nasus Larynx $26: 435 \sim 439,1999$.

原稿受付：平成15年 4 月 28 日 原稿採択 : 平成15年 7 月 16 日 別刷請求先：上原 健 干903-0125 沖縄県中頭郡西原町上原207 琉球大学医学部耳鼻咽喉科学教室 